\title{
The Significance of the Rhetorical Ambiguity in Isaiah 54:16
}

\author{
NisSim AmZallag and Shamir Yona (BEN GURION UNIVERSity OF \\ THE NEGEV, ISRAEL)
}

\begin{abstract}
The ambiguity in Isa 54:16a concerning the identity of the subject (YHWH or the smith) of the two verbs relating a metallurgical action (to blow and to cast) is identified here as a rhetorical device intending to conceal the essential relation of YHWH with metallurgy. Integrated in the whole Isa 54 chapter, this device becomes a plea for the definitive replacement of Edom with Israel as YHWH'S people, exactly as in Isa 34-35 and Isa 61-63.
\end{abstract}

KEYWORDS: primeval Yahwism; kbd-YHwH; copper metallurgy; anti-Edomite ideology; book of Isaiah.

\section{A INTRODUCTION}

Isaiah 54:16 rarely attracts special attention in scholarship, its meaning being generally considered quite clear. In the first hemiverse, YHWH claims that he has created ברא) the smiths; in the second, he takes credit for the creation of users of the instruments of destruction (produced by the smiths). Such rhetoric is unsurprising in Isa 40-55, a section well known for developing the theme of YHWH's control of the entirety of the universe and its elements. ${ }^{1}$ Scholars have even identified literary devices that typically promote "rhetoric of monotheism" in Isa 40-55. ${ }^{2}$ They include the use of formulae claiming the exclusivity and incomparability of the god and self-predications in which YHWH affirms his

* Submitted: 04/05/2018; peer-reviewed: 08/06/2018; accepted: 18/07/2018. Nissim Amzallag and Shamir Yona, "The Significance of the Rhetorical Ambiguity in Isaiah 54:16," OTE 31 no. 2 (2018): 323-338. DOI: https://doi.org/10.17159/23123621/2018/v31n2a4.

1 This is why this second section of the book is considered essential for the development of the monotheistic faith. See Robert K. Gnuse, No Other Gods: Emergent Monotheism in Israel (Sheffield: Sheffield Academic Press, 1997), 142-44; André Lemaire, The Birth of Monotheism: The Rise and Disappearance of Yahwism (Washington: Biblical Archaeological Society, 2007), 106-7; Nathan MacDonald, "Monotheism and Isaiah," in The Interpretation of Isaiah, ed. Hugh G. M. Williamson and David Firth (Leicester: IVP, 2009), 43-61; Hywel Clifford, "Deutero-Isaiah and Monotheism," in Prophecy and Prophets in Ancient Israel, ed. John Day (New York: T\&T Clark, 2010), 267-89.

2 Clifford "Deutero-Isaiah," 273-77. 
power of salvation and his status as a supreme divine entity who controls the whole earth and its transformations. ${ }^{3}$ Such self-glorification is characterised by an abundance of rhetorical questions and nominal sentences with participial predicates, in which the subject remains the divine self - even if this is not explicitly expressed. ${ }^{4}$ The extensive use of the verb $b r^{\prime}$ as to create in Isa 40-55 integrates such rhetoric trends well. ${ }^{6}$ This is why the double use of $b r^{2}$ in Isa 54:16, evoking the creation of both the makers and the users of weapons, should come as no surprise. It aptly combines the dual dimensions of consolation and hope that characterise Isa $40-55$ as well as the self-predication and selfglorification of YHWH that are identified with the rhetoric of monotheism in the same set of verses. ${ }^{7}$ More specifically, it supports the idea of divine protection of Israel against its enemies, which is expressed in the subsequent verse (Isa 54:17) when YHWH assures Israel that he has the power to render weapons inefficient insofar as they are trained against his protected nation. ${ }^{8}$

All these considerations do much to bolster the general consensus concerning the meaning and interpretation of Isa $54: 16$, reflected by the ESV translation of this verse:

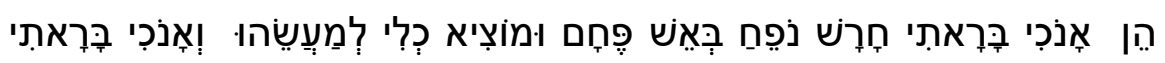

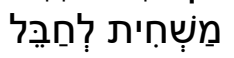

3 Paul E. Dion, "The Patriarchal Traditions and the Literary Form of the Oracle of Salvation," CBQ 29 (1967): 198-206; Claus Westermann, Basic Forms of Prophetic Speech (Philadelphia: Westminster, 1967), 125 and Claus Westermann, Isaiah 40-66: A Commentary (Philadelphia: Westminster, 1969), 26; Morgan L. Phillips, "Divine Self-Predication in Deutero-Isaiah," BR 16 (1971): 32-51.

4 Paul E. Dion, "Le genre littéraire sumérien de l'hymne à soi-même et quelques passages du Deutero-Isaiah," RB 74 (1967): 215-34.

5 In Isa 40-55, the verb $b r^{\prime}$ evokes YHWH as creator of the earth (e.g. Isa 40:28; 42:5), of mankind (Isa 45:12) and of Israel (Isa 43:1,15). It also relates specifically to the creation of YHWH's faithful servants (Isa 43:7).

6 The verb $b r^{\prime}$, among the prophetic books, occurs once in Isa 1-39 (Isa 4:5); fifteen times in Isa 40-55 (Isa 40:26, 28; 41:20; 42:5; 43:1, 7, 15; 45:7, 7, 8, 12, 18 [2x]; 54:16 [2x]) and four times in Isa 56-66 (Isa 57:19; 65:17, 18 [2x]). In comparison, this verb is found only three times in Ezekiel (Ezek 21:35; 28:13, 15), once in Jeremiah (Jer 31:22), Amos (Amos 4:13) and Malachi (Mal 2:10), and nowhere else in the prophetic books.

7 Eugene H. Merrill, “Isaiah 40-55 as Anti-Babylonian Polemic," GTJ 8 (1987): 1315.

8 Westermann, Isaiah 40-66, 279. This interpretation is already defended by medieval exegetes, such as David Kimhi. 
Behold, I have created the smith who blows the fire of coals and produces a weapon for its purpose; I have also created the ravager to destroy. ${ }^{9}$

Several observations, however, suggest that the meaning of this verse is not as simple as it may appear. In the second hemiverse, for example, an ambiguity remains concerning the nature of both the subject and the complement of the pi 'el hbl (= to destroy) due to its infinitive aspect. This ambiguity is well reflected by the English translation I [YHWH] have created the ravager to destroy. ${ }^{10}$ Uncertainty also remains concerning the silent complement of this infinitive verb. Whereas most translators identify it with people that are victims of destruction, other translators and exegetes identify the weapon produced by the smith as the object of destruction in $16 \mathrm{~b} .{ }^{11}$

Ambiguity may also be detected in the first hemiverse. The first verb, the subject of which is clearly YHWH, is followed by a complement (the smith), itself followed by two participles (verb 2 qal nph =to blow, and verb 3 hip 'il yṣ', generally translated as to produce or to go forth), each with its own complement. The difference in conjugation between verb 1 and verbs 2-3 may be indicative of a change in the identity of the subject. This difference, however, may also allude to the meaning of these verbs: the perfect tense of $b r^{\prime}$ corresponding to the completion of the action (the creation of the smith at the time of origin) and the participles of the second and third verbs expressing the permanent involvement of YHWH and/or the smith in the metalworking activity. Such ambiguity in 16a concerning the subject of verbs $2-3$ is reflected in a translation closer to the original Hebrew text: "See, it is I who created the blacksmith who fans the coals into flame and forges a weapon fit for its work; And it is I who have created the destroyer to wreak havoc." 12 The absence of a comma following the smith

9 A similar translation is found in the ASV; CEB; HCSB; The Darby Translation; Hebrew Names Version; Jubilee Bible 2000; KJV; Lexham English Bible; Orthodox Jewish Bible; Douay-Rheims Catholic Bible; RSV; Third Millennium Bible; The Webster Bible. In some version, this interpretation is even extended to stress the causal link between YHWH creating the smith and the tools he produces. See, for example, the God's word version: "I've created blacksmiths to fan the coals into flames and to produce useful weapons. I've also created destroyers to bring destruction."

10 In Isa 40-55, the subject of such a second, infinitive, verb may be the subject or the complement of the previous conjugated verb (see for example Isa 45:1 and 43:20 respectively).

11 See, for example, the Genève translation (French). This opinion has already been defended by the medieval exegete Abraham Abulafia. Such a complementarity in reference to YHWH as the agent involved in both the production of weapons (16a) and their destruction (16b) recalls the creation by YHWH of both peace and evil as evoked in Isa 45:7.

12 This translation is found, for example, in the NIV and in the Complete Jewish Bible. 
identifies him as the subject of verbs $2-3$, but the ambiguity remains in a text originally devoid of punctuation. ${ }^{13}$ The aim of this study is to interrogate whether this ambiguity was intentionally introduced and, if so, for what purpose.

\section{B ANALYSIS OF THE STRUCTURE OF ISAIAH 54:16}

Ambivalence in the meaning of Isa 54:16 is reflected by the interrelations of the three segments of the first hemiverse:

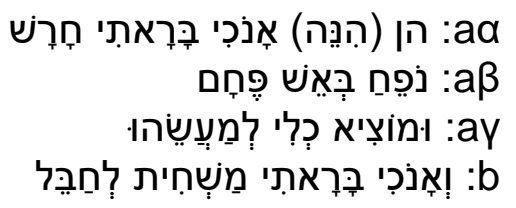

\section{The Rhetoric of Self-Predication}

Both hemiverses of Isa 54:16 begin with the pronoun ānōkî, followed by the verb $b r$, conjugated in the first-person singular. This redundancy specifically emphasises that it is YHWH who is the agent of the action. On the one hand, the pronoun $\bar{a} n \bar{o} k \hat{\imath}$ is well-suited to the context of self-predication that characterises Isa 40-55. On the other hand, this emphasis extends its influence to the second and third verbs in 16a, as in Isa 43:12a, where the divine I ( $\bar{a} n \bar{o} k \hat{\imath})$ precedes three successive verbs similarly conjugated in the first-person singular: "It is I (אנכי) [who] declared, saved and proclaimed, there is no foreigner among you." The very same reality is found in the two hemiverses of Isa 45:12: "It is I (אנכ) [who] made the earth and man on it I created (בראתי); It was I (אני), my hands stretched out the heavens, and all their host I commanded (בויתי)."

The situation is different in Isa 49:25b, where the self-emphasis of the divine I is expressed by a double mention of $\bar{a} n \bar{o} k \hat{\imath}$, each occurrence of the pronoun referring to its specific subsequent verb: "For those who contend with you, it is I (אנכי) [who] will contend; your children it is I (אנכי) [who] will save." This reuse of $\bar{a} n \bar{o} k \hat{\imath}$ in this latter example is apparently explained by the fact that the action related in the two ensuing segments (to contend and to save) are so contrasting that the same self-emphasis device cannot encompass both.

If we transpose these observations to Isa 54:16, we may explain the double use of $\bar{a} n \bar{o} k \hat{\imath}$ at the beginning of the two hemiverses by the difference in the actions referenced in both. This implies that the divine endeavour cannot be restricted to the act of creation, which is similar in both. Furthermore, if the double presence of $\bar{a} n \bar{o} k \hat{\imath}$ in Isa 54:16 projects onto the difference in the actions

13 Interestingly, a pausal indication (zaqef qațan) is introduced in the MT immediately after the mention of the smith (חרש), a feature that instead promotes YHWH as the subject of verbs 2-3. 
attributed to YHWH, we may conclude that YHWH is probably the subject of verbs other than $b r^{\prime}$, the production of metallic weapons, in 16a as well.

\section{The Missing Relative Cause}

Assuming that the smith is the subject of the second and third verbs in 16a, we should infer that the segments $16 a \beta \gamma$ are relative clauses of $16 \mathrm{a} \alpha$. The absence of a marker of the relative clauses cannot in itself exclude this eventuality because in biblical Hebrew, since many relative clauses are asyndetic, i.e., devoid of a specific marker. ${ }^{14}$ The prefix $\mathrm{n}$, however, may occasionally serve as a relative pronoun ${ }^{15}$ and its use for introducing a relative clause is frequently encountered in Isa 40-55 (e.g., Isa 40:26; 41:13; 42:17; 43:16-17; 44:26-28; $47: 13 ; 51: 9-10)$. This use of the $\mathrm{n}$ prefix as a relative pronoun is explicitly observed in oracles where YHWH appears in both in the first- and the thirdperson singular, as in Isa 52: 6: "Therefore my people shall know my name; Therefore in that day they shall know that it is I (אני) who speak: here I am." Consequently, the absence of a marker of the relative clause in Is 54:16a is not a trivial feature. Rather, it supports the assumption that the ambiguity surrounding the subject of verbs 2-3 in Isa 54:16a was intentional.

\section{The Dative in the 16ay Complement}

In the third clause, the verb yș' ( $h i p$ ' $i l$ ), generally translated as brings forth, is followed by a complement, the expression kly lm 's hw. The waw-dative here designates specifically who is concerned by the activity leading to the fabrication

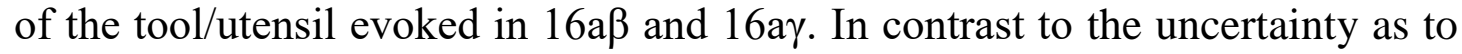
the subject of verbs 2-3, here, the waw suffix unambiguously refers to the smith. ${ }^{16}$ Ostensibly, then, this third clause may be translated as follows: he brings forth an instrument for his [= the smith] work/purpose. The successful fabrication of an object that fulfils the artisan's intent, however, evokes no surprise. It is expected that identifying the smith as being also the subject of the verb creates a redundancy. ${ }^{17}$ Some translators simply erased this final indication $^{18}$; others preserved it but attempted to eliminate the triviality by

14 Bruce K. Waltke and Michael P. O'Connor, An Introduction to Biblical Hebrew Syntax (Winona Lake: Eisenbrauns, 1990), 338.

15 Waltke and O'Connor, Biblical Hebrew Syntax, 339; Paul Joüon and Tamitsu Muroaka, A Grammar of Biblical Hebrew (Rome: Pontifical Institute, 2008), 504-5.

16 This use is similar to the waw-dative found in Gen 1:11-12 associating each seed and fruit to its specific species.

17 This problem is well reflected in the NRSV: "See it is I who have created the smith who blows the fire of coals, and produces a weapon fit for its purpose" (16a).

18 Thus, the 16a hemiverse is translated as "I create the blacksmith, who builds a fire and forges weapons" (GNB) or "I've created blacksmiths to fan the coals into flames and to produce useful weapons" (God's Word translation). 
transforming its meaning. ${ }^{19}$ The redundancy disappears, however, once YHWH becomes the subject in 16ay: the clause specifies that YHWH's active participation is necessary for the successful outcome of the utensils that the smith intends to produce. This is another argument towards the identification of YHWH as the potential subject of verbs 2 and 3 in Isa 54:16a.

\section{VERSE 16 IN ITS LITERARY CONTEXT}

An examination of the content of vv. 15 and 17 may help us to identify who performs the actions reported in Isa $54: 16 a .^{20}$

Verse 15: If anyone stirs up strife [to you], it is not from me ( אֶפֶ מאוֹתִי Whoever stirs up strife with you shall fall because of you.

Verse 17: No weapon that is fashioned against you shall succeed, and every tongue that rises against you in judgment you shall refute; This is the heritage of the servants of YHWH, and their vindication from

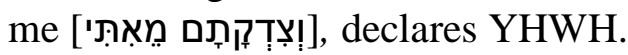

Verse 15 informs us that YHWH is not involved in the plans and actions of the enemies of Israel. This claim obviously introduces a dissonance with YHWH's overwhelming power, expressed in v. 16, and with the monotheistic doctrine extensively argued and developed in Isa 40-55. This claim is especially intriguing after YHWH proclaims himself as even being the source of evil in Isa $45: 7$.

This contradiction evanesces, however, once YHWH becomes the active agent in 16a, because the specific need to deny any divine participation in the conflicts against Israel (v. 15) becomes a consequence of his systematic participation in metalworking related in v. 16a. The content of v. 17 fits this interpretation well. After claiming that the weapons oriented against Israel are produced against his will (vv. 15-16), YHWH promises at the beginning of v. 17 that these weapons will remain inefficient against his protected nation: "No weapon that is fashioned against you shall succeed." 21

19 For example, in the New Century version, we read: "See, I made the blacksmith. He fans the fire to make it hotter, and he makes the kind of tool he wants." Alternately, in the Message Bible, the 16a hemiverse is translated as follows: "I create the blacksmith who fires up his forge and makes a weapon designed to kill."

20 This investigation is possible because v. 16 is generally approached as originally clustered with vv. 15 and 17. See Lars G. Rignell, A Study of Isaiah ch 40-55 (Lund: CWK Gleerup, 1956), 84-7; Antoon Schoors, I am God your Saviour: A Form-Critical Study of the Main Genres in Is XL-LV (Leiden: Brill, 1973), 85; Roy F. Melugin, The Formation of Isaiah 40-55 (Berlin: de Gruyter, 1976), 171-72.

21 A similar divine obliteration by YHWH of the power of metallic weapons is found in Isa 41:2a: "He shall give as 'āpār his sword." This description apparently evokes the 
The opposition of YHWH to the production of weapons against Israel in v. 15 and his promise of neutralising them in v. 17 are sufficient for ensuring divine protection. The insertion of $\mathrm{v}$. 16 between them is unnecessary, if this latter simply mentions YHWH creating the smith ab initio. However, recalling that YHWH is especially involved in metalworking (YHWH as subject of verbs 2 and 3 in 16a), it becomes necessary to justify how weapons may be produced against his will (v. 15), and even for confirming, through the mastering by YHWH of the metallurgical processes (v. 16), his ability to destroy them by a reverse oxidation process. The relationship between vv. 15-17 confirms, therefore, that YHWH is truly the subject of the three verbs in 16a.

\section{THE METALLURGICAL ACTIVITY OF YHWH}

The mention of utensils ( $k l y)$ in Isa 54:16ay indicates that the first hemiverse is not confined to the production of weapons (as expected from the second hemiverse), but rather evokes metallurgy in general. This invites an examination of the nature of the relationship between YHWH and metallurgy.

\section{Metallurgy as Essential Dimension in Ancient Yahwism}

The metallurgical background of ancient Yahwism is suggested first by traces in the Bible of a pre-Israelite cult of YHWH among the Qenites (identified as metalworkers originating in southern Canaan), ${ }^{22}$ and traces of Qenite legislation in the Pentateuch (e.g., the Sotah proscription in Num 5:10-31). ${ }^{23}$ The hypothesis of the Qenite origin of ancient Yahwism is also supported by YHWH's origin in southern Canaan (Deut 33:2; Judg 5:4; Hab 3:3) and by non-biblical documents that link YHWH to the Shossu people of Sinai and the Arabah Valley (including

formation of deep corrosion (copper disease) which makes the weapons unusable. See Nissim Amzallag, "The Forgotten Meaning of 'āpār in Biblical Hebrew," JAOS 137 (2017): 774-75.

22 Joseph Blenkinsopp, "The Midianite-Kenite Hypothesis revisited and the Origin of Judah," JSOT 33 (2008): 131-53; John Day, "Cain and the Kenites," in Homeland and Exile: Biblical and Ancient Near Eastern Studies in Honour of Bustenay Oded, ed. Gershon Galil, Mark Geller, and Alan Millard (Leiden: Brill, 2009), 335-346; Marleen E. Mondriaan, "Who were the Kenites?" OTE 24 (2011): 414-30; Thomas Römer, "The Revelation of the Divine Name to Moses and the Construction of a Memory about the Origins of the Encounter Between YHWH and Israel," in Israel's Exodus in Transdisciplinary Perspective:Text, Archaeology, Culture and Geoscience, ed. Thomas E. Levy, Thomas Schneider, and William H. C. Propp (Berlin: Springer, 2015), 314; Nissim Amzallag, "Why is the Cain Genealogy (Gen 4:17-24) Integrated into the Book of Genesis?" ANES 55 (2018): 23-50.

23 Nissim Amzallag and Shamir Yona, "The Kenite Origin of the Sotah Prescription (Numbers 5:11-31)," JSOT 41 (2017): 383-412. 
explicit mention of the region of Seir) in the Bronze Age. ${ }^{24}$ The spread of ethnic markers of this population in southeastern Canaan during the Iron Age suggests that YHWH was worshipped in Edom, the nation explicitly identified with copper production in the Iron Age, concurrent with his becoming the national deity of the Israelites. ${ }^{25}$ Traces of such a metallurgical background of ancient Yahwism are revealed by YHWH's volcanic theophany (e.g. Exod 19:16-19) and mode of action (e.g. Nah 1:4-6) because volcanism in antiquity was a typical attribute of the gods who patronised metallurgy. ${ }^{26}$ The close relationship between YHWH and the "burning serpents" (e.g. Num 21:6-8; 2 Kgs 18:4; Isa 6:2-3) and the metallurgical symbolism of the latter supports this notion. ${ }^{27}$ The $k b d-Y H W H$, a material reality of an exceedingly hot, liquid, and radiant nature in the Bible, has been likened to molten metal, the unshaped nature of which fulfills the interdiction of the representation of YHWH (e.g., Deut 4:15). ${ }^{28}$ If molten metal is traditionally identified in ancient Israel as divine theophany ( $=k b d-\mathrm{YHWH})$, one may expect YHWH to be systematically present in the metalworkers' shop, at least once the metals reach a molten state. This is why YHWH's participation

24 See Raphael Giveon, Les bédouins Shosou des documents Égyptiens (Leiden: Brill, 1971), 235-36 and docs 16, 25, 33, 38. The affinities of early Israel with the Shossu (see Giveon, Les bédouins, 267-71; Anson F. Rainey, "Israel in Merenptah's Inscription and Reliefs," IEJ 51 [2001]: 73-75) strengthen the assumption of a southeastern homeland for ancient Yahwism.

25 Thomas E. Levy, "You Shall Make for Yourself No Molten Gods: Some Thoughts on Archaeology and Edomite Ethnic Identity," in Sacred History, Sacred Literature: Essays on Ancient Israel, the Bible, and Religion in Honor of R. E. Friedman, ed. Shawna Dolansky (Winona Lake: Eisenbrauns, 2008), 242; Thomas E. Levy, Erez BenYosef, and Mohammad Najjar, "New Perspectives on the Iron Age Copper Production and Society in the Faynan Region, Jordan," in Eastern Mediterranean Metallurgy and Metalwork in the Second Millennium BCE, ed. Vassiliki Kassianidou and George Papasavvas (Oxford: Oxbow, 2012), 197-214; Justin Kelley, "Toward a New Synthesis of the God of Edom and YHWH," AntOr 7 (2009), 255-80. The specific mention of "YHWH from Samaria and YHWH from Teman" in Kuntillet Ajrud (8th Century BCE, see William G. Dever, "Asherah, Consort of YHWH? New Evidence from Kuntillet 'Ajrûd," BASOR 255 [1984], 21-37) confirms this assumption.

26 Jacob E. Dunn, "A God of Volcanoes: Did Yahwism Take Root in Volcanic Ashes?" JSOT 38 (2014): 387-424; Nissim Amzallag, "Some Implications of the Volcanic Theophany of YHWH on his Primeval Identity," AntOr 12 (2014): 11-38.

27 See Nissim Amzallag, "The Serpent as a Symbol of Primeval Yahwism," Sem 58 (2016): 208-39. The representation of the celestial universe in Ezek 1 as a giant furnace (Godfrey R. Driver, “Ezekiel's Inaugural Vision,” VT 1 [1951]: 60-62) also alludes to a metallurgical background such as this.

28 Nissim Amzallag, "The Material Nature of the Divine Radiance and its Theological Implications," SJOT 29 (2015): 80-96. 
in metalworking should not be restricted to the mere creation of the first smith $a b$ initio in Isa 54:16.

\section{The Divine Blowing}

Blowing air onto a fire is essential for bringing a metal to its melting point, a temperature much higher than the heat produced by a normal fire. ${ }^{29}$ Thus, if metallurgy is an essential dimension of ancient Yahwism, it is not surprising to see the deity involved in the blowing process that leads to his theophany. This essential participation of the "breath of YHWH" in boosting fire is suggested in Ps 104:4 ("He makes his messengers winds, his ministers a flaming fire") ${ }^{30}$ and in Job 4:9 ("By the breath of God they perish, and by the blast of his 'nose' [אף] they are consumed").

The many interactions among fire, wind, and the divine "nose" (אף) and even nostrils (אפיים) also suggest that this imagery designates a tuyère by which YHWH blows. ${ }^{31}$ Such a metallurgical dimension of the breath emanating from YHWH's 'nose' is revealed in Isa 66:15, where the first hemiverse evokes divine action through wind and fire ("For behold, YHWH in fire will come, and like the whirlwind his chariots") and the second hemiverse evokes their combination ("to blow [להשיב] $]^{32}$ his 'nose' in heat, his roaring in flames of fire").

A representation of YHWH blowing on metallurgical fire is found in Ezek 21:36a: "And I will pour out upon you my indignation; With the fire of my wrath I will blow (אפיח) upon you; and I will give you into the hands of fiery men, smiths of destruction." This verse may hardly be considered as a metaphor,

29 The essential participation of a divine power in blowing on metallurgical fire is not surprising, because blowing air is required to attain temperatures necessary for smelting metalworking copper (about $1200^{\circ} \mathrm{C}$ ). Before modern chemistry, the preternatural properties of fire (otherwise reaching temperatures up to $700-800^{\circ} \mathrm{C}$ ) following air boosting were inexplicable absent the constant involvement of a divine being in imparting special power to this ethereal but otherwise inert element. Even though the smith was the agent who manipulated the bellows, the power to attain the preternatural temperatures was provided by a divine principle, which, consequently, was necessarily present in the workshop.

30 According to Patrick D. Miller, "Fire in the Mythology of Canaan and of Israel," $C B Q 27$ (1966): 259, and Steve A. Wiggins, "Tempestuous Wind Doing YHWH's Will: Perceptions of the Wind in the Psalms," SJOT 13 (1999): 16, their mention in two parallel hemiverses promotes their homology.

${ }^{31}$ See Nissim Amzallag, "What Are the 'Long Nostrils' of YHWH?" Rel 8/9 (2017); Art. \#190, 15 pages; doi: 10.3390/rel8090190; and Nissim Amzallag, "Beyond Nose and Anger - A Reinterpretation of אף in YHWH's Context," RB 125 (2018): 5-28.

32 The text remains obscure as long as $l h s ̌ y b$ is understood as the hif šwb (= to return). However, lhšyb is also the hif of $n s ̌ b$ (= to blow, e.g. Gen 15:11; Isa 40:7; Ps 147:18) and this "windy" context clarifies the meaning of the second hemiverse. 
because the pouring of a hot molten substance is not only a theophany but also a divine mode of action. ${ }^{33}$ The subsequent mention of metalworkers in this verse confirms such an interaction between YHWH and the metalworkers. Exactly as in Isa 54:16, this verse evokes YHWH blowing on the fire by which smiths produce weapons of destruction. ${ }^{34}$

\section{The Action of Casting}

The second action is evoked in 16ay by the participle $y s^{\prime}$ ( $h i p$ ' $i$ l). Extensively used in the Bible (about 280 times), the hip 'il yṣ ' may denote leading out, causing a person or people to go out (e.g. Gen 45:1, Deut 1:27), to send over (Ezra 10:3), or to liberate (Ps 31:5). ${ }^{35}$ This verb is also used to evoke the release of animals (e.g., Gen 8:17), water (e.g., Num 20:8), wind (Jer 10:13) and even fire (e.g. Ezek 28:18) and, by extension, it denotes bringing forth and even producing (e.g., Gen 1:12; Num 17:23). ${ }^{36}$ Given that the last-mentioned usage includes metalworking (e.g., Deut 4:20a), ${ }^{37}$ the frequent translation of $y s^{\prime}$ ' (hip ' $i l$ ) in Isa 54:16a as to produce or to bring forth is not surprising. In Prov 25:4, Exod 32:24, and Job 23:10, however, the verb yș ' (qal) apparently evokes the flowing of molten metal from its source (a crucible or a furnace). ${ }^{38}$ This suggests that the

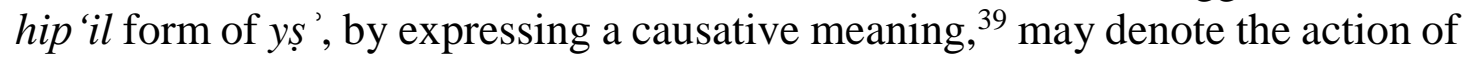
pouring/casting molten metal. ${ }^{40}$ This interpretation is especially relevant in Isa 54:16a because casting liquid metal is the logical extension of the action of air blasting $(16 \mathrm{a} \beta)$ that is needed to bring the metal to its melting point. In view of the relationship between molten metal and $k b d-Y H W H$, it is likely that the ambiguity concerning the subject of the third verb is intentional: it stresses YHWH's involvement in an activity that leads both to his material revelation and the production of copper implements.

33 Jean Koenig, "Aux origines des théophanies iahvistes," RHR 169 (1966): 1-36; Deena E. Grant, "Fire and the Body of YHWH," JSOT 40 (2015): 149.

${ }^{34}$ YHWH is also represented in Ezek 22:20-21 as blowing on fire for the purpose of melting metals; this vision, however, is merely a metaphor for the destruction of the Israelites.

35 These latter meanings are especially exploited for relating the active involvement of YHWH in the exodus (e.g. Exod 3:8; Amos 9:7).

36 See HALOT 2:426; DCH 4:261-64, Horst D. Preuss, "יצא,, TDOT 6:225-49.

37 See also $1 \mathrm{Kgs}$ 8:51; Jer 11:4.

38 See Raymond C. van Leeuwen, "A Technical Metallurgical Usage of יצא," ZAW 98 (1986): 112-13; Richard J. Clifford, Proverbs: A Commentary (Louisville: Westminster John Knox, 1999), 222-23; William H. C. Propp, Exodus 19-40 (New York: Doubleday, 2006), 662.

39 Preuss, TDOT 6:236.

40 Van Leeuwen, "Technical Metallurgical"; DCH 4:261; Michael V. Fox, Proverbs 10-31 (New Haven: Yale University Press, 2009), 779. 


\section{E RHETORICAL AMBIGUITY AS LITERARY STRATAGEM}

The active participation of YHWH in the metallurgical workshop, in Isa 54:16, is deduced here from three sets of independent observations: dissection of the structure of v. 16, analysis of its relationship with its adjacent verses, and reference to the metallurgical background of ancient Yahwism. Each of these sets suffices, on its own, to conclude that a rhetorical ambiguity between YHWH and the smith has been intentionally introduced concerning the subject of verbs 2-3 in 16a. What comes next is to elucidate its significance.

\section{The Theological Conflict}

In v. $17 \mathrm{a}$, the divine promise of protection against a metallic weapon is accompanied by a similar promise to neutralise the recriminations against Israel. The parallelism of the two assurances is emphasised by the use of similar expressions in both. The oracle is therefore aimed at a people in both military and ideological conflict with Israel. This conflict seems asymmetrical for the additional reason that it is Israel, and not its enemy, that must defend itself against accusations (17a).

The mention of YHWH denying his attachment to the enemy in v. 15 (אֶפֶס מאוֹתִי) using almost the same expression with which he expresses his

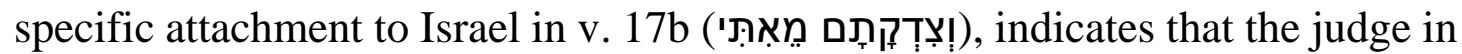
this conflict is YHWH. From the wording of the divine verdict (YHWH vindicates the Israelites and denies all association with its enemies), we may deduce that the conflict here is over the status of YHWH's "chosen" people, which is disputed between Israel and its enemies. The only conflict of such a nature in the Bible is the struggle for authority over Yahwism between the former worshippers from Mount Seir (Qenites, Edom) and the new congregation from Mount Zion (Israel), stigmatised by the tumultuous transfer of primogeniture rights and/or firstborn status from Esau to Jacob in Gen 27.41

The problematic way in which the primogeniture rights were transferred from Esau to Jacob and, especially, the lack of divine approbation of Jacob's initiative in Gen 27 finds an echo in Isa 40-55. There, to the recriminations of the Israelites against YHWH, the prophet decries the fundamental sin committed by their forefather Jacob:

${ }^{26}$ Put me in remembrance; let us argue together; set forth your case, that you may be proved right. ${ }^{27}$ Your first father sinned; and your mediators transgressed against me. ${ }^{28}$ Therefore I will profane the

${ }^{41}$ Nissim Amzallag, Esau in Jerusalem: The Rise of a Seirite Religious Elite in Zion at the Persian Period (Paris: Gabalda, 2015), 53-57. 
334 Amzallag \& Yona, "Rhetorical Ambiguity," OTE 31/2 (2018): 323-338

princes of the sanctuary, and deliver Jacob to utter destruction and Israel to reviling" (Isa 43:26-28). ${ }^{42}$

From such a perspective, the content of Isa 54:15-17 resembles an antidote to the original sin of the Israelites' forefather because it introduces a change in YHWH's attitude toward the two conflicting peoples. With this oracle, YHWH's commitment to Israel overcomes his involvement in metalworking (v. 16), especially if the weapons produced are intended for use against Israel (vv. $15,17)$. From now on, in the event of conflict between the two, the interests and care of the new people (Israel) surmount the commitments traditionally attached to the erstwhile people of YHWH, Edom and the metalworkers.

\section{The New Covenant in Isaiah 54}

Isaiah 40-55 is generally approached as a book centring around a polemic against the Assyrian-Babylonian culture and religion, motivated by the wish to prevent the Israelite exiles' assimilation into their host culture and religion and to encourage their return to the land and god of their fathers. ${ }^{43}$ This is why the destroyer in Isa 54 is traditionally identified with the Assyrians and/or the Babylonians, the conquering empires responsible for the collapse of the kingdoms of Israel and Judah and the exile. ${ }^{44}$

However, the metaphor in vv. 1-14 carries another message. YHWH's gift of jewels and precious stones to Israel in Isa 54:11-13 symbolises wedding gifts to a new bride (= voluntary choice of $\mathrm{YHWH}$ ). The promise of divine protection in vv. 15-17 becomes an extension of the marital metaphor in which the husband commits to protecting his (new) wife. ${ }^{45}$ Therefore, the wedding metaphor in Isa 54:1-14 introduces a theological novelty: YHWH, who is absent on the occasion of the transfer of primogeniture (Gen 27), now explicitly assents to the transfer of religious authority from Edom to Israel. This novelty invalidates the Edomites' recriminations (Isa 54:17a) concerning the Israelites' selfpromotion as the holy people of YHWH. The rhetoric ambiguity in v. 16 clearly integrates such a tendency. On the one hand, the divine participation in the smiths' workshop is not denied, because such a denial would divest YHWH of

42 The Israelites' doubts about the position of the deity are also well expressed in Malachi: "I have loved you [Israel], says YHWH. But you say: How have you loved us? Is not Esau Jacob's brother? YHWH declares: Yet I have loved Jacob, but Esau I have hated. I have laid waste his hill country and left his heritage to jackals of the desert" (Mal 1:2-3).

43 Merrill, "Isaiah 40-55."

44 James W. Watts. Isaiah 34-66 (Waco, TX: Word Books, 1987), 800; Joseph Blenkinsopp, Isaiah 40-55 (New York: Doubleday, 2000), 364.

45 Concerning the cohesiveness of all of Isa 54 or at least of the section comprising vv 11-17, see Westermann, Isaiah 40-66, 278; Schoors, God your Saviour, 85; S. L. Stassen, "Marriage (and Related) Metaphors in Isaiah 54:1-17," JSem 6 (1994): 57-73. 
many of his essential attributes. On the other hand, the ambiguity surrounding the subject of the verbs in $16 a \beta \gamma$ makes this divine presence easy to dismiss, promoting the idea of the disengagement of YHWH in regard to metallurgy. This tendency is strengthened by the parallel suggested between the metalworker (16a) and the destroyer (16b), which, after identifying the metalworkers with evil, denies their closeness with YHWH. This rhetorical strategy contributes to the idea of the replacement of Edom with Israel as the people of YHWH.

\section{$3 \quad$ The Anti-Edomite Position in Isaiah 54}

The present study reveals an importance of Isa 54 that far transcends the simple use of a marital metaphor to promote the idea that YHWH defends Israel against its enemies. Beyond this first layer of interpretation, it appears that this chapter develops the theme of theological substitution of Edom by Israel at YHWH's instigation. Consequently, the content of Isa 54 should be regarded as homologous to the oracle evoking the definitive destruction of Edom by YHWH (Isa 34) as a prelude to the definitive salvation of Israel (Isa 35). ${ }^{46}$ The very same dynamic is observed in the last part of Isaiah, where the oracle of Edom's destruction by YHWH (Isa 63:1-6) is mirrored by the perspective of Israel's redemption (Isa 61:1-62:12). ${ }^{47}$ This is why Isa 54 as a whole should be considered homologous in its message to the anti-Edomite theological claim identified in Isa 34 and Isa $63 .{ }^{48}$

\section{F CONCLUSION}

The present study has shown that, instead of arguing against the traditional commitment of YHWH to the people of Edom, the Isaian author elaborated in Isa 54:16 a sentence that lends itself to two interpretations, one fitting the traditional view and the other diverging from it. The author also elaborated a literary environment that spontaneously promotes the second meaning without having to expose any theological argument that denies the first one. This stratagem extends the trend of demystification of metallurgy and its theological component already advanced in Isa 40:19-20; 41:6-7; 44:9-12, 46:6. In all these sources, metalworkers are implicitly criticised (and sometimes even openly mocked) for casting idols. Exactly as the case in Isa 54:16, the condemnation of idolatry in all these mentions (by conflating producers and users of the metal artifacts) promotes the idea that metalworkers betrayed YHWH and his covenant, even without expressing such a charge openly. The rhetorical ambiguity identified in Isa 54:16 fits well into the general tendency toward silent

46 See Claire R. Mathews, Defending Zion: Edom's Desolation and Jacob's Restoration (Isaiah 34-35) in Context (Berlin: de Gruyter, 1995), 128-30, 163-67; Elie Assis, Identity in Conflict: The Struggle between Esau and Jacob, Edom and Israel (Winona Lake: Eisenbrauns, 2016), 121-23, 130.

47 Mathews, Defending Zion, 81; Assis, Identity in Conflict, 134-37.

48 Assis, Identity in Conflict, 128-30. 
336 Amzallag \& Yona, "Rhetorical Ambiguity," OTE 31/2 (2018): 323-338

denegation of primeval Yahwism in Isa 40-55, a necessary counterpart of the development of a theology of salvation focusing on the rebirth of Israel.

\section{BIBLIOGRAPHY}

Amzallag, Nissim. "Some Implication of the Volcanic Theophany of YHWH on his Primeval Identity." AntOr 12 (2014): 11-38

. "The Material Nature of the Divine Radiance and its Theological Implications." SJOT 29 (2015): 80-96. . Esau in Jerusalem: The Rise of a Seirite Religious Elite in Zion at the Persian Period. Gabalda: Paris, 2015.

" "The Serpent as a Symbol of Primeval Yahwism." Sem 58 (2016): 208-39 "What Are the 'Long Nostrils' of YHWH?" Rel 8/9 (2017). Art. \#190. 15 pages. https://doi.org/10.3390/rel8090190 . "The Forgotten Meaning of 'āpār in Biblical Hebrew." JAOS 137 (2017): 767-83.

"Why is the Cain Genealogy (Gen 4:17-24) Integrated into the Book of Genesis?” ANES 55 (2018): 23-50.

. "Beyond Nose and Anger - A Reinterpretation of אף in YHWH's Context." $R B 125$ (2018): 5-28.

Amzallag, Nissim and Shamir Yona. "The Kenite Origin of the Sotah Prescription (Numbers 5.11-31).” JSOT 41 (2017): 383-412.

Assis, Elie. Identity in Conflict: The Struggle between Esau and Jacob, Edom and Israel. Winona Lake: Eisenbrauns, 2016.

Blenkinsopp, Joseph. Isaiah 40-55. New York: Doubleday, 2000.

."The Midianite-Kenite Hypothesis Revisited and the Origin of Judah." JSOT 33 (2008): 131-53.

Botterweck, G. Johannes and Helmer Ringgren, eds. Theological Dictionary of the Old Testament. Grand Rapids: Eerdmans, 1990.

Clifford, Hywel. "Deutero-Isaiah and Monotheism." Pages 267-89 in Prophecy and Prophets in Ancient Israel. Edited by John Day. New York: T\&T Clark, 2010.

Clifford, Richard J. Proverbs: A Commentary. Louisville: Westminster John Knox, 1999.

Clines, David J. A. The Dictionary of Classical Hebrew. Sheffield: Sheffield Phoenix Press, 2011.

Day, John. "Cain and the Kenites." Pages 335-46 in Homeland and Exile: Biblical and Ancient Near Eastern Studies in Honour of Bustenay Oded. Edited by Gershon Galil, Mark Geller, and Alan Millard. Leiden: Brill, 2009. https://doi.org /10.1163/ej.9789004178892.i-648.100

Dever, William G. "Asherah, Consort of YHWH? New Evidence from Kuntillet 'Ajrûd." BASOR 255 (1984): 21-37.

Dion, Paul E. "The Patriarchal Traditions and the Literary Form of the Oracle of Salvation.” CBQ 29 (1967): 198-206.

. "Le genre littéraire sumérien de l'hymne à soi-même et quelques passages du Deutero-Isaiah.” $R B 74$ (1967): 215-34.

Driver, Godfrey R. “Ezekiel's Inaugural Vision.” VT 1 (1951): 60-62.

Dunn, Jacob E. "A God of Volcanoes: Did Yahwism Take Root in Volcanic Ashes?" JSOT 38 (2014): 387-424. 
Fox, Michael V. Proverbs 10-31. New Haven: Yale University Press, 2009.

Giveon, Raphael. Les bédouins Shosou des documents Égyptiens. Leiden: Brill, 1971.

Gnuse, Robert K. No Other Gods: Emergent Monotheism in Israel. Sheffield: Sheffield Academic Press, 1997.

Grant, Deena E. "Fire and the Body of YHWH." JSOT 40 (2015): 139-61.

Joüon, Paul and Tamitsu Muroaka. A Grammar of Biblical Hebrew. Rome: Pontifical Institute, 2008.

Kelley, Justin. "Toward a New Synthesis of the God of Edom and YHWH." Antiguo Oriente 7 (2009): 255-80.

Koehler, Ludwig and Walter Baumgartner. The Hebrew and Aramaic Lexicon of the Old Testament. Leiden: Brill, 2001. https://doi.org/10.3406/rhr.1966.8291

Koenig, Jean. "Aux origines des théophanies iahvistes.” RHR 169 (1966): 1-36.

Lemaire, André. The Birth of Monotheism: The Rise and Disappearance of Yahwism. Washington: Biblical Archaeological Society, 2007.

Levy, Thomas E. "You Shall Make for Yourself No Molten Gods: Some Thoughts on Archaeology and Edomite Ethnic Identity." Pages 239-55 in Sacred History, Sacred Literature: Essays on Ancient Israel, the Bible, and Religion in Honor of R. E. Friedman. Edited by Shawna Dolansky. Winona Lake: Eisenbrauns, 2008.

Levy, Thomas E., Erez Ben-Yosef, and Mohammad Najjar. "New Perspectives on the Iron Age Copper Production and Society in the Faynan Region, Jordan." Pages 197-214 in Eastern Mediterranean Metallurgy and Metalwork in the Second Millennium BCE. Edited by Vassiliki Kassianidou and George Papasavvas. Oxford: Oxbow Books, 2012.

MacDonald, Nathan. "Monotheism and Isaiah." Pages 43-61 in The Interpretation of Isaiah. Edited by Hugh G. M. Williamson and David G. Firth. Leicester: IVP, 2009.

Mathews, Claire R. Defending Zion: Edom's Desolation and Jacob's Restoration (Isaiah 34-35) in Context. De Gruyter, Berlin, 1995. https://doi.org/10.1515/9783110814927

Melugin, Roy F. The Formation of Isaiah 40-55. De Gruyter: Berlin, 1976.

Merrill, Eugene H. "Isaiah 40-55 as Anti-Babylonian Polemic." GTJ 8 (1987): 3-18.

Miller, Patrick D. "Fire in the Mythology of Canaan and of Israel." CBQ 27 (1966): 256-61.

Mondriaan, Marleen E. "Who were the Kenites?" OTE 24 (2011): 414-30.

Phillips, Morgan L. "Divine Self-Predication in Deutero-Isaiah.” BR 16 (1971): 32-51.

Propp, William H. C. Exodus 19-40. New York: Doubleday, 2006.

Rainey, Anson F. "Israel in Merenptah's Inscription and Reliefs." IEJ 51 (2001): $57-$ 75.

Rignell, Lars G. A Study of Isaiah ch 40-55. Lund: CWK Gleerup, 1956.

Römer, Thomas. "The Revelation of the Divine Name to Moses and the Construction of a Memory about the Origins of the Encounter Between YHWH and Israel." Pages 305-15 in Israel's Exodus in Transdisciplinary Perspective: Text, Archaeology, Culture and Geoscience. Edited by Thomas E. Levy, Thomas Schneider, and William H. C. Propp, Berlin: Springer, 2015.

Schoors, Antoon. I am God your Saviour: A Form-Critical Study of the Main Genres in Is XL-LV. Leiden: Brill, 1973. https://doi.org/10.1163/9789004275478

Stassen, S. L. "Marriage (and Related) Metaphors in Isaiah 54:1-17." JSem 6 (1994): 57-73. 
338 Amzallag \& Yona, "Rhetorical Ambiguity," OTE 31/2 (2018): 323-338

Van Leeuwen, Raymond C. “A Technical Metallurgical Usage of יצא." ZAW 98 (1986): 112-13.

Waltke, Bruce K. and Michael P. O'Connor. An Introduction to Biblical Hebrew Syntax. Winona Lake: Eisenbrauns, 1990.

Watts, James W. Isaiah 34-66. Waco, TX: Word Books, 1987.

Westermann, Claus. Basic Forms of Prophetic Speech. Philadelphia: Westminster, 1967.

Isaiah 40-66: A Commentary. Philadelphia: Westminster, 1969.

Wiggins, Steve A. "Tempestuous Wind Doing YHWH's Will: Perceptions of the Wind in the Psalms." SJOT 13 (1999): 3-23.

Dr Nissim Amzallag. Department of Bible, Archaeology and Ancient Near Eastern Studies. Ben Gurion University of the Negev, POB 653, Beer Sheba 84105, Israel.nissamz@ post.bgu.ac.il.

Prof. Shamir Yona. Department of Bible, Archaeology and Ancient Near Eastern Studies. Ben Gurion University of the Negev, POB 653, Beer Sheba 84105, Israel. shamiry@bgu.ac.il. 